\title{
Enhanced chromium (VI) removal using activated carbon modified by zero valent iron and silver bimetallic nanoparticles
}

\author{
Babak Kakavandi ${ }^{1}$, Roshanak Rezaei Kalantary ${ }^{2}$, Mahdi Farzadkia ${ }^{2}$, Amir Hossein Mahvi ${ }^{3,4}$, Ali Esrafili ${ }^{2}$, Ali Azari ${ }^{3{ }^{*}}$, \\ Ahmad Reza Yari ${ }^{5}$ and Allah Bakhsh Javid ${ }^{6}$
}

\begin{abstract}
Recently, adsorption process has been introduced as a favorable and effective technique for the removal of metal ions from aqueous solutions. In the present study, bimetallic nanoparticles consisting of zero valent iron and silver were loaded on the activated carbon powder for the preparation of a new adsorbent (PAC-Fe/Ag). The above adsorbent was characterized by using XRD, SEM and TEM techniqes. Experimental data were exploited for kinetic, equilibrium and thermodynamic evaluations related to the adsorption processes. The $\mathrm{Cr}(\mathrm{VI})$ adsorption process was found to be favorable at $\mathrm{pH} 3$ and it reached equilibrium state within $60 \mathrm{~min}$. The stirring rate did not have a significant effect on the adsorption efficiency. Furthermore, the monolayer adsorption capacity of $\mathrm{Cr}(\mathrm{VI})$ based on the Langmuir model was measured to be $100 \mathrm{mg} / \mathrm{g}$. The experimental equilibrium data were fitted to the Freundlich adsorption and pseudo second-order models. According to the thermodynamic study, the adsorption process was spontaneous and endothermic in nature, indicating the adsorption capacity increases with increasing the temperature. The results also revealed that the synthesized composite can be potentially applied as a magnetic adsorbent to remove $\mathrm{Cr}(\mathrm{VI})$ contaminants from aqueous solutions.
\end{abstract}

Keywords: Bimetallic, Chromium, Activated carbon, nZVI, Adsorption

\section{Introduction}

Along with industries' development, the contaminants originating from their activities have significantly increased. Heavy metals are the main pollutants end up to the environment by these activities. High toxicity of these metals causes serious problems to the ecosystem even at low concentrations [1]. Chromium $(\mathrm{Cr})$ is one of the most dangerous heavy metals that has many applications in the metal cleaning and plating baths, painting, tannery and fertilizer industries [2]. Cr mainly exists in two stable oxidation states, $\mathrm{Cr}(\mathrm{VI})$ and $\mathrm{Cr}$ (III). $\mathrm{Cr}(\mathrm{VI})$ form is more toxic to living things than $\mathrm{Cr}$ (III) due to its carcinogenicity, toxicity and high aqueous solubility $[1,3]$. When the concentration of this metal reaches $0.1 \mathrm{mg} / \mathrm{g}$ of the body weight, it can be heavily lethal. Therefore, The United States Environmental Protection

\footnotetext{
*Correspondence: Ali_azari67@yahoo.com

${ }^{3}$ Department of Environmental Health Engineering, School of Public Health,

Tehran University of Medical Sciences, Tehran, Iran

Full list of author information is available at the end of the article
}

Agency (US-EPA) and World Health Organization (WHO) have set the maximum allowable concentration (MAC) for $\mathrm{Cr}$ at 0.1 and $0.05 \mathrm{ppm}$ in drinking water, respectively [3,4].

The different methods namely, membrane filtration, electrochemical precipitation, ion exchange, adsorption, reduction of $\mathrm{Cr}(\mathrm{VI})$ to $\mathrm{Cr}(\mathrm{III})$, reverse osmosis, evaporation, chelating, solvent extraction, electrolysis and cyanide treatment were all employed for the removal of $\mathrm{Cr}$ (VI) from water and wastewater [1,2,5]. Most of these methods have some drawbacks such as low efficiency, high demand for energy, high cost, requiring special chemicals, and the problems related to the disposal of sludge $[5,6]$. While; the adsorption process due to its ease of operation, flexibility in design, low cost and high efficiency, has been effectively applied to removal of heavy metals including $\mathrm{Cr}(\mathrm{VI})$ [2].

In previous studies, various adsorbents such as granular activated carbon (GAC), powder activated carbon $(\mathrm{PAC})$, mineral cartridge, biological and agricultural waste 
have been used for the removal of $\mathrm{Cr}$ (VI) [7-10]. Amongst these adsorbents, PAC due to its high porosity, large surface area and high efficiency has gained more interests than the others. In a comparative study by Jung et al., they compared the removal of $\mathrm{Cr}(\mathrm{VI})$ using PAC, chitosan, and single/multi-wall carbon nanotubes and found out that the maximum adsorption capacity of PAC $(46.9 \mathrm{mg} / \mathrm{g})$ was the highest within the studied adsorbents [5].

However, the main problem concerning PAC lies within its reusability and separation of it from aqueous solution. Thus, establishing the optimal conditions to facilitate the separation of PAC from the solution after the adsorption process seems to be essential. A way to achieve this purpose is to induce the magnetic properties into an adsorbent followed by the use of a magnet for physical separation. This so-called method has been widely used for the last few years due to its simplicity and high-speed [11,12]. Lv et al. [2] used nano Zero Valent Iron (nZVI)- $\mathrm{Fe}_{3} \mathrm{O}_{4}$ nanocomposite as an adsorbent for the removal of $\mathrm{Cr}(\mathrm{VI})$ and they demonstrated that $96.4 \%$ of $\mathrm{Cr}(\mathrm{VI})$ could be removed within $2 \mathrm{~h}$ under the conditions of $\mathrm{pH} 8.0$ and initial $\mathrm{Cr}$ (IV) concentration of $20 \mathrm{mg} / \mathrm{L}$. They also reported that the experimental data were fitted best to the pseudo second-order kinetic and Langmuir and Freundlich isotherm models [2].

Having used nZVI as iron source to magnetize PAC, we also used it as a reducing agent $(\mathrm{E} 0=-0.42 \mathrm{~V})$ facilitating the reduction of $\mathrm{Cr}(\mathrm{VI})$ to $\mathrm{Cr}(\mathrm{III})$ according to the following reactions:

$$
\begin{aligned}
& \mathrm{Fe}^{\mathrm{o}}+\mathrm{HCrO}^{-}{ }_{4}+7 \mathrm{H}^{+} \rightarrow \mathrm{Fe}^{3+}+\mathrm{Cr}^{3+}+4 \mathrm{H}_{2} \mathrm{O} \\
& \mathrm{Fe}^{\mathrm{o}}+\mathrm{CrO}^{2-}{ }_{4}+8 \mathrm{H}^{+} \rightarrow \mathrm{Fe}^{3+}+\mathrm{Cr}^{3+}+4 \mathrm{H}_{2} \mathrm{O} \\
& 2 \mathrm{Fe}^{\mathrm{o}}+\mathrm{Cr}_{2} \mathrm{O}^{2-}{ }_{7}+14 \mathrm{H}^{+} \rightarrow 2 \mathrm{Fe}^{3+}+2 \mathrm{Cr}^{3+}+7 \mathrm{H}_{2} \mathrm{O}
\end{aligned}
$$

As shown in Figure 1, $\mathrm{Fe}^{\mathrm{o}}$ has high affinity toward losing electron, for this reason, upon entering water it reacts with $\mathrm{Cr}(\mathrm{VI})$ and converts it to $\mathrm{Cr}(\mathrm{III})$. Then, $\mathrm{Cr}(\mathrm{III})$ is adsorbed by PAC and removed from the solution. Since the reactivity of nZVI is low, it is necessary to employ high active metals such as $\mathrm{Ag}, \mathrm{Pb}, \mathrm{Ni}$ and $\mathrm{Cu}$ in order to increase its catalytic capability [13]. These metals can accelerate the detoxification of $\mathrm{Cr}$ (VI) through protecting nZVI particles from the surface oxidation [3].

Herein, we used silver nanoparticles, due to their high electrochemical potential $(\mathrm{E} 0=0.8)$, to enhance the catalytic ability of nZVI [14]. Having high specific area -at nanometer scale-, they could be used as a unique adsorbent for removal of pollutants $[15,16]$. Based on the above-mentioned findings, some researchers loaded Ag nanopartices on the adsorbents such as activated carbon

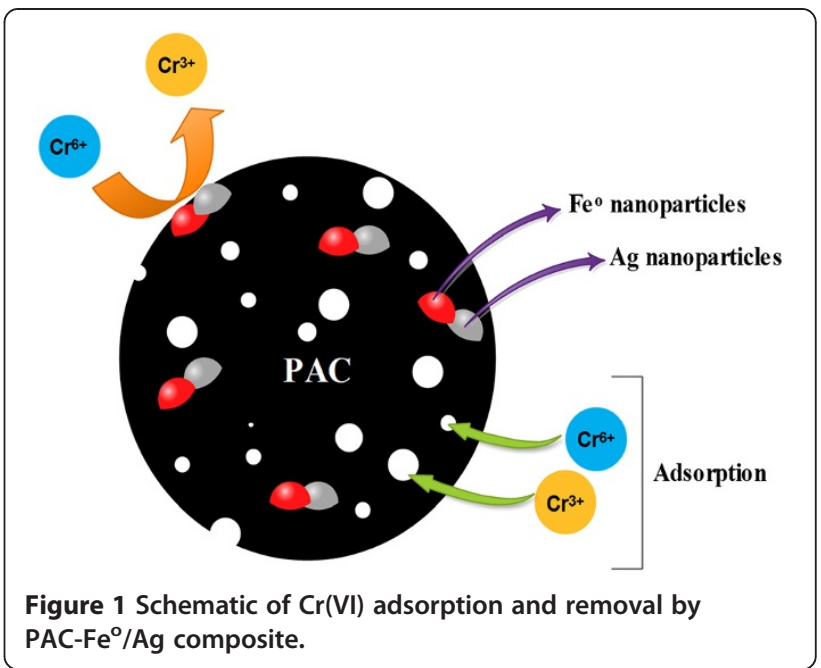

and multiwall carbon nanotubes for the removal of dyes and heavy metals from the aqueous solutions $[17,18]$.

So far, the removal of $\mathrm{Cr}(\mathrm{VI})$ using $\mathrm{PAC}-\mathrm{Fe}^{\mathrm{o}} / \mathrm{Ag}$ as an adsorbent has not been reported in the literature. This prompted us to combine the advantages of activated carbon and $\mathrm{Fe}^{\mathrm{O}} / \mathrm{Ag}$ bimetallic nanoparticles for the preparation of magnetic composite $\mathrm{PAC}-\mathrm{Fe}^{\mathrm{o}} / \mathrm{Ag}$ as a new adsorbent for the removal of $\mathrm{Cr}(\mathrm{VI})$ from aqueous solutions.

\section{Material and method \\ Adsorbent}

All Chemicals used in this work were of analytical grade ( $>95 \%$ purity) and provided by Merck (Merck, Darmstadt, Germany). $\mathrm{FeSo}_{4} .7 \mathrm{H}_{2} \mathrm{O}, \mathrm{NaBH}_{4}, \mathrm{HCl}, \mathrm{NaOH}$ and $\mathrm{AgNO}_{3}$ were used for the synthesis of PAC. Herein, we employed co-precipitation and reduction methods for the synthesis of $\mathrm{PAC}^{-\mathrm{Fe}^{\mathrm{o}}}$ [19]. Initially, $10 \mathrm{~g} \mathrm{FeSO}_{4} \cdot 7 \mathrm{H}_{2} \mathrm{O}$ was dissolved in $200 \mathrm{~mL}$ of methanol:water $(30: 70, \% \mathrm{v} / \mathrm{v})$. Then, $10 \mathrm{~g}$ PAC was added into the resulting mixture. The $\mathrm{pH}$ of the mixture was adjusted at 7 with $3.8 \mathrm{M}$ $\mathrm{NaOH}$ followed by the addition of an aqueous $\mathrm{NaBH}_{4}$ solution $(4 \% \mathrm{w} / \mathrm{v})$. After that, the whole mixture was stirred in a jar test for $45 \mathrm{~min}$. The synthesized PAC-Fe ${ }^{\circ}$ particles were then separated from the liquid phase using a magnet $(1.3 \mathrm{~T})$ and washed at least three times with acetone and dried for $4 \mathrm{~h}$ under the $\mathrm{N}_{2}$-purged environment. The ferrous iron was reduced to ZVI and coated on PAC according to the following reaction Eq (4):

$$
\begin{aligned}
4 \mathrm{Fe}_{3} & +3 \mathrm{BH}_{4}^{-}+9 \mathrm{H}_{2} \mathrm{O} \rightarrow 4 \mathrm{Fe}^{\mathrm{o}}+3 \mathrm{H}_{2} \mathrm{BO}_{3}{ }^{-} \\
& +12 \mathrm{H}^{+}+6 \mathrm{H}_{2}
\end{aligned}
$$

In the next step, $10 \mathrm{~g} \mathrm{PAC}-\mathrm{Fe}^{\mathrm{o}}$ powder was added to a diluted solution of $\mathrm{AgNo}_{3}(0.01 \mathrm{M})$ and the mixture was 
mixed on a shaker-incubator (HACH-HQ-USA) for 40 min at $300 \mathrm{rpm}$ at $200 \pm 1^{\circ} \mathrm{C}$ (flash mixing and high temperature) [20]. Finally, $\mathrm{NaBH}_{4} 3 \mathrm{M}$ was added to complete the following reaction:

$$
2 \mathrm{AgNo}_{3}+2 \mathrm{Fe}^{\mathrm{o}} \rightarrow 2 \mathrm{Ag}+\mathrm{Fe}\left(\mathrm{No}_{3}\right)_{2}
$$

The resulting bimetallic nanoparticles were separated by a magnet and immediately washed many times with water and finally dried under $\mathrm{N}_{2}$-purged for $2 \mathrm{~h}$.

\section{Adsorbate}

A stock solution of $\mathrm{Cr}(\mathrm{VI})(1000 \mathrm{mg} / \mathrm{L})$ was prepared by dissolving the required amount of potassium dichromate $\left(\mathrm{K}_{2} \mathrm{Cr}_{2} \mathrm{O}_{7}\right)$ in water and further diluted to prepare the solutions in the concentration range of $4-100 \mathrm{mg} / \mathrm{L}$. The residual concentration of $\mathrm{Cr}(\mathrm{VI})$ was measured using a UV-VIS spectrophotometer (7400CE CECIL) at $540 \mathrm{~nm}$ by diphenylcarbazine method.

\section{Characterization of the synthesized adsorbent}

The micro image, surface morphology, size and distribution of $\mathrm{Fe}^{\mathrm{o}} / \mathrm{Ag}$ were analyzed by scanning electron microscopy (SEM, edxS360, Mv2300). The crystalline structure of the bimetallic nanoparticles coated on PAC was investigated by X-ray diffraction (XRD, Quantachrome, NOVA2000) using $\mathrm{Cu}-\mathrm{k} \alpha$ radiation and $\lambda=1.54 \AA$ $40 \mathrm{kVp}$ and $30 \mathrm{~mA}$. The dimension and shape of the adsorbent was determined by transmission electron microscopy (TEM, PHILIPS, EM 208 S) with $100 \mathrm{keV}$.

\section{Batch adsorption experiments}

All experiments were carried out under a batch condition using $100 \mathrm{ml}$ Erlenmeyer flasks, each containing 50 $\mathrm{ml}$ of $4 \mathrm{mg} / \mathrm{L} \mathrm{Cr}(\mathrm{VI})$ and a certain amounts of the adsorbent. The effect of $\mathrm{pH}$ in the range of 3-9 on the adsorption efficiency was studied under the following condition: contact time of $120 \mathrm{~min}$ and the stirring rate of $200 \mathrm{rpm}$. Herein, the $\mathrm{pH}$ of solution was adjusted using $0.1 \mathrm{M} \mathrm{HCl}$ or/and $0.1 \mathrm{M} \mathrm{NaOH}$. The optimal contact time was then established under the condition of $0.3 \mathrm{~g} / \mathrm{L}$ adsorbent, $4 \mathrm{mg} / \mathrm{L} \mathrm{Cr}(\mathrm{VI})$ and room temperature. The Erlenmeyers were stirred in the range of 50, 100, 200, 300 and $400 \mathrm{rpm}$ to determine the optimal agitation speed.

The effects of adsorbent dosage and initial concentration of $\mathrm{Cr}(\mathrm{VI})$ were examined in the range of $0.1-2 \mathrm{~g} / \mathrm{L}$ and 4-100 $\mathrm{mg} / \mathrm{L}$, respectively. The effect of solution temperature on $\mathrm{Cr}(\mathrm{VI})$ removal efficiency was investigated at $25,30,40$ and $50^{\circ} \mathrm{C}$. It is worth noting that a shakerincubator was employed to stabilize the temperature. All experiments were done in triplicate and the mean values were taken as the final results. The amount of $\mathrm{Cr}(\mathrm{VI})$ adsorbed onto the adsorbent at each contact time $\left(\mathrm{q}_{\mathrm{e}}\right)$ was calculated using the equation (6):

$$
\mathrm{q}_{\mathrm{e}}=\left(\mathrm{C}_{\mathrm{o}}-\mathrm{C}_{\mathrm{e}}\right)\left(\frac{\mathrm{V}}{\mathrm{m}}\right)
$$

Where $C_{0}$ and $C_{e}$ are initial and equilibrium concentration of $\mathrm{Cr}(\mathrm{VI})(\mathrm{mg} / \mathrm{L})$, respectively. $\mathrm{V}$ is the volume of the aqueous phase (L) and $\mathrm{m}$ is the mass of $\mathrm{PAC}-\mathrm{Fe}^{\mathrm{O}} / \mathrm{Ag}(\mathrm{g})$.

\section{Adsorption isotherm}

Adsorption isotherm describes the equilibrium of the adsorption material at the surface of adsorbent (i.e., at the surface boundary). Adsorption isotherms were obtained from the data derived from the regression analysis. The Langmuir and Freundlich isotherm models were used to evaluate $\mathrm{Cr}(\mathrm{VI})$ adsorption on the $\mathrm{PAC}-\mathrm{Fe}^{\mathrm{o}} / \mathrm{Ag}$. The linear equations and parameters regarding the Langmuir and Freundlich isotherm models are presented in the Table 1.

$\mathrm{k}_{\mathrm{L}}(\mathrm{L} / \mathrm{mg})$ is the empirical constant related to energy and $\mathrm{q}_{\mathrm{m}}(\mathrm{mg} / \mathrm{g})$ represents the maximum adsorption capacity. $\mathrm{k}_{\mathrm{F}}$ and $\mathrm{n}$ are the Freundlich constants related to the adsorption capacity and intensity, respectively. The $\mathrm{q}_{\mathrm{m}}$ and $\mathrm{k}_{\mathrm{L}}$ parameters are calculated from the slope and intercept of the $\mathrm{C}_{\mathrm{e}} / \mathrm{q}_{\mathrm{e}}$ plot versus $\mathrm{C}_{\mathrm{e}}$, respectively. The Freundlich isotherm parameters $\left(\mathrm{k}_{\mathrm{F}}\right.$ and $\left.\mathrm{n}\right)$ are also calculated from the slope and intercept of the $\operatorname{lnC}_{\mathrm{e}}$ plot versus $\ln q_{e}$, respectively.

The favorability of $\mathrm{Cr}(\mathrm{VI})$ adsorption onto $\mathrm{PAC}-\mathrm{Fe}^{\mathrm{o}}$ / $\mathrm{Ag}$ was investigated using a dimensionless parameter, $R_{L}$, derived from the Langmuir model. It expresses the essential characteristics of the isotherm model. $R_{L}$ is defined as follows:

$$
\mathrm{R}_{\mathrm{L}}=\frac{1}{1+\mathrm{k}_{\mathrm{L}} \mathrm{C}_{0}}
$$

Where, $\mathrm{C}_{\mathrm{o}}$ is the initial concentration of $\mathrm{Cr}(\mathrm{VI})$. The adsorption will be favorable if $R_{L}$ lies within 0 and 1 . For $R_{L}>1$, the adsorption is unfavorable; for $R_{L}=1$ and 0 , the adsorption is linear and irreversible, respectively [21].

\section{Kinetics of adsorption}

Chemical kinetics deals with the experimental conditions influencing the rate of a chemical reaction. Herein, two kinetic models including the pseudo first-order and pseudo

Table 1 The linear equations and parameters regarding $\mathrm{Cr}(\mathrm{VI})$ adsorption onto $\mathrm{PAC}-\mathrm{Fe} \% / \mathrm{Ag}$

\begin{tabular}{llll}
\hline Model & & Linear equation & Parameters \\
\hline Isotherms & Langmuir & $\frac{\mathrm{C}_{\mathrm{e}}}{\mathrm{q}_{\mathrm{e}}}=\frac{1}{\mathrm{q}_{\mathrm{m}} \mathrm{K}_{\mathrm{L}}}+\frac{1}{\mathrm{q}_{\mathrm{m}}} \mathrm{C}_{\mathrm{e}}$ & $\mathrm{K}_{\mathrm{L}}$ and $\mathrm{q}_{\mathrm{m}}$ \\
& Freundlich & $\ln \mathrm{q}_{\mathrm{e}}=\ln \mathrm{k}_{\mathrm{f}}+\frac{1}{\mathrm{n}} \ln \mathrm{C}_{\mathrm{e}}$ & $\mathrm{K}_{\mathrm{f}}$ and $\mathrm{n}$ \\
Kinetics & Pseudo first-order & $\ln \left(\mathrm{q}_{\mathrm{e}}-\mathrm{q}_{\mathrm{t}}\right)=\ln \mathrm{q}_{\mathrm{e}}-\mathrm{k}_{\mathrm{f}} \mathrm{t}$ & $\mathrm{q}_{\mathrm{e}}$ and $\mathrm{k}_{\mathrm{f}}$ \\
& Pseudo second-order & $\frac{\mathrm{t}}{\mathrm{q}_{\mathrm{t}}}=\frac{1}{\mathrm{k}_{2} \mathrm{q}_{\mathrm{e}}{ }^{2}}+\frac{1}{\mathrm{q}_{\mathrm{e}}} \mathrm{t}$ & $\mathrm{q}_{\mathrm{e}}$ and $\mathrm{K}_{2}$ \\
\hline
\end{tabular}


second-order models were applied for the modeling of the adsorption process of $\mathrm{Cr}(\mathrm{VI})$ onto $\mathrm{PAC}-\mathrm{Fe}^{\mathrm{O}} / \mathrm{Ag}$. The linear equations of the mentioned models along with respective parameters are given in Table 1.

$\mathrm{K}_{1}(1 / \mathrm{min})$ and $\mathrm{k}_{2}(\mathrm{~g} /(\mathrm{mg} \cdot \mathrm{min}))$ are the constant rate of the pseudo first-order and pseudo second-order models, respectively. The parameters related to the mentioned kinetic models can be obtained from the plots of $\ln \left(\mathrm{q}_{\mathrm{e}}-\mathrm{q}_{\mathrm{t}}\right)$ and $\mathrm{q}_{\mathrm{t}} / \mathrm{t}$ against $\mathrm{t}$.

\section{Thermodynamics of adsorption}

Thermodynamics of adsorption is the systematic study dealing with the transformation of matter and energy in systems as they approach equilibrium state [12]. In thermodynamic studies, the determination of standard enthalpy $\left(\Delta \mathrm{H}^{\mathrm{o}}\right)$, standard free energy $\left(\Delta \mathrm{G}^{\mathrm{o}}\right)$ and standard entropy $\left(\Delta S^{\circ}\right)$ is necessary. The values of $\Delta H^{\circ}, \Delta S^{\circ}$ and $\Delta \mathrm{G}^{\mathrm{o}}$ are obtained by using the following equations:

$$
\begin{aligned}
& \operatorname{lnk}_{\mathrm{d}}=\frac{\Delta \mathrm{S}^{\circ}}{\mathrm{R}}-\frac{\Delta \mathrm{H}^{\circ}}{\mathrm{R}} \frac{1}{\mathrm{~T}} \\
& \Delta \mathrm{G}^{\circ}=\Delta \mathrm{H}^{\circ}-\mathrm{T} \Delta \mathrm{S}^{\circ} \\
& \mathrm{K}_{\mathrm{d}}=\frac{\mathrm{q}_{\mathrm{e}}}{\mathrm{C}_{\mathrm{e}}}
\end{aligned}
$$

Where $\mathrm{q}_{\mathrm{e}}$ is the amount of $\mathrm{Cr}(\mathrm{VI})$ adsorbed at equilibrium $(\mathrm{mg} / \mathrm{g})$ and $\mathrm{C}_{\mathrm{e}}$ is the equilibrium concentration of $\mathrm{Cr}(\mathrm{VI})$ in solution $(\mathrm{mg} / \mathrm{L})$. $\mathrm{R}(8.314 \mathrm{~J} / \mathrm{mol} \mathrm{K})$ is the universal gas constant and $\mathrm{T}\left({ }^{\circ} \mathrm{K}\right)$ is the solution temperature. The parameters of $\Delta \mathrm{H}^{\mathrm{o}}$ and $\Delta \mathrm{S}^{\mathrm{o}}$ can be obtained from the intercept and slope of the van't Hoff plot (lnk $k_{d}$ versus $1 / \mathrm{T})$, respectively.

\section{Results and discussion \\ Adsorbent features}

The morphology, size and surface of PAC and PAC-Fe / Ag were analyzed by SEM. Figure 2(a) shows the image of SEM for PAC before being coated with $\mathrm{Fe}^{\mathrm{O}} / \mathrm{Ag}$ bimetallic nanoparticles. It shows that the PAC has good porosity and high adsorption capacity. Figure 2(b) indicates the SEM analysis for $\mathrm{PAC}-\mathrm{Fe}^{\mathrm{O}} / \mathrm{Ag}$, from which it can be deducted that the PAC structure is uniform compared with that of Figure 2(a). In Figure 2(b), white dots on the surface of the adsorbent represent the $\mathrm{Fe}^{\mathrm{O}} / \mathrm{Ag}$ bimetallic particles which have an agglomeration structure and scattered abnormality. Figure 2(b) also shows that $\mathrm{Fe}^{\mathrm{o}}$ and $\mathrm{Ag}$ particles were synthesized in nano scale (diameter of $82 \mathrm{~nm}$ ).

The XRD pattern of the synthesized adsorbent in the angle range of $2 \theta=5-70^{\circ}$, applying $\mathrm{Cu} k \alpha$ radiation $(\lambda=$ $1.5 \mathrm{~A}^{\circ}$ ) is shown in Figure $3(\mathrm{a})$. In this pattern, carbon $(\mathrm{C})$ and silver $(\mathrm{Ag})$ have been indicated at the peaks of $24.7^{\circ}$ and $37.8^{\circ}$, respectively. Moreover, the peaks at the angles of $45.5^{\circ}$ and $55.6^{\circ}$ confirm the presence of $\mathrm{Fe}^{\mathrm{O}}$ particles in the adsorbent structure. Generally, the XRD analysis confirmed that the $\mathrm{Fe}^{\mathrm{o}}$ and $\mathrm{Ag}$ particles have been successfully coated on the PAC surface. Figure 3(a) also shows the magnetic properties of $\mathrm{PAC}-\mathrm{Fe}^{\mathrm{O}} / \mathrm{Ag}$ in magnetic separation process by using a magnet field.

The shape of $\mathrm{Fe}^{\mathrm{O}} / \mathrm{Ag}$ bimetallic nanoparticles was analyzed by using TEM micrographs with $100 \mathrm{keV}$ (Figure 3 (b)). It can be deducted that the synthesized absorbent structure was polygon with irregular shape. Figure 3(a, insert) reflects the synthesized composite has a high magnetic sensitivity in the presence of an external magnetic field. Finally, it can be concluded that $\mathrm{PAC}-\mathrm{Fe}^{\mathrm{O}} / \mathrm{Ag}$ can be potentially applied as a magnetic adsorbent the for removal of $\mathrm{Cr}(\mathrm{VI})$ contaminants from aqueous solutions and, subsequently, the secondary pollution could be avoided.

\section{Effect of solution $\mathrm{pH}$}

The solution $\mathrm{pH}$ is one the main effective parameters which could have a significant role in controlling the adsorption process [22]. The effect of $\mathrm{pH}$ on $\mathrm{Cr}$ (VI) adsorption is shown in Figure 4(a). As shown in Figure 4 (a), the maximum $\mathrm{Cr}(\mathrm{VI})$ removal occurred at acidic $\mathrm{pH}$ which can be due to the electrostatic attraction between the $\mathrm{Cr}(\mathrm{VI})$ anions and the positive charges located on the adsorbent surface. At acidic $\mathrm{pH}$ conditions, the predominant species of $\mathrm{Cr}(\mathrm{VI})$ come in various forms $\left(\mathrm{Cr}_{2} \mathrm{O}_{7}^{2-}, \mathrm{HCrO}_{4}^{-}, \mathrm{Cr}_{3} \mathrm{O}_{10}^{2-}\right.$ and $\left.\mathrm{Cr}_{4} \mathrm{O}_{13}^{2-}\right)$, which they all
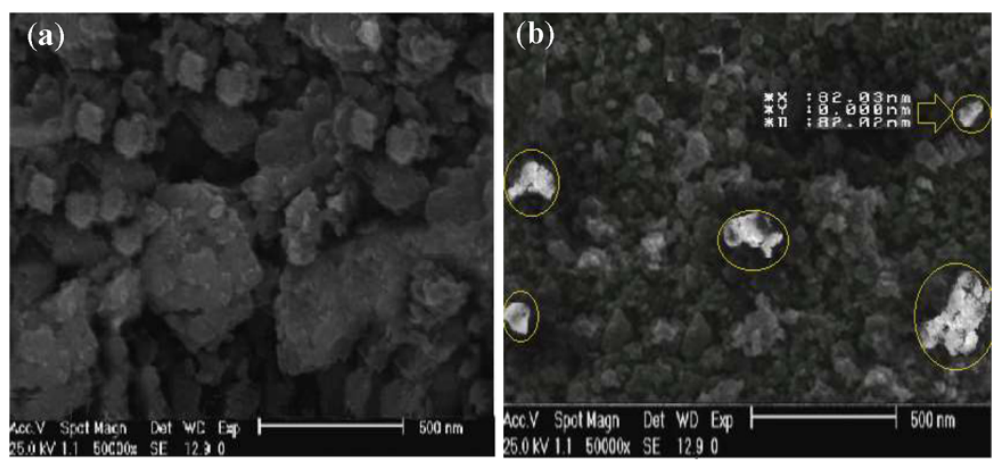

Figure 2 SEM images of PAC (a) and PAC-Fe $/ \mathrm{Ag}(\mathrm{b})$. 

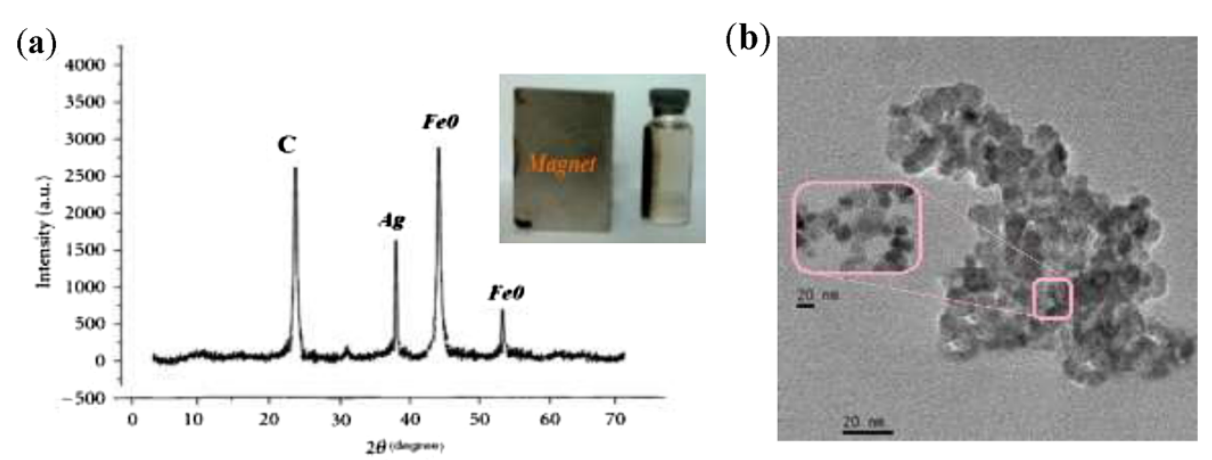

Figure $3 \mathrm{XRD}$ analysis of $\mathrm{PAC}-\mathrm{Fe} / \mathrm{Ag}(\mathrm{a})$, magnetic separation of $\mathrm{PAC}-\mathrm{Fe} / \mathrm{Ag}$ from aqueous solution (insert) and TEM image for $\mathrm{PAC}-\mathrm{Fe} / \mathrm{Ag}$ (b).

bare negative charge(s) [3]. But, the fall in $\mathrm{Cr}(\mathrm{VI})$ removal as a result of the rise in $\mathrm{pH}$ may be due to the fact that at higher $\mathrm{pH}$, the $\mathrm{PAC}-\mathrm{Fe}^{\mathrm{O}} / \mathrm{Ag}$ surface is negatively charged and subsequently enhances the electrostatic repulsion between $\mathrm{Cr}(\mathrm{VI})$ ions and the adsorbent, leading to the release of the adsorbed $\mathrm{Cr}(\mathrm{VI})$ species off the $\mathrm{PAC}-\mathrm{Fe}^{\mathrm{o}} / \mathrm{Ag}$ surface $[1,23]$.

In addition; Since $\mathrm{Fe}^{\mathrm{O}}$ particles could be easily oxidized to $\mathrm{Fe}^{2+}$ by $\mathrm{Cr}(\mathrm{VI})$ at $\mathrm{pH}<6$, they can promote the adsorption of $\mathrm{Cr}(\mathrm{VI})$. Therefore, it is concluded that the reduction process (i.e., the reduction of $\mathrm{Cr}(\mathrm{VI})$ to $\mathrm{Cr}(\mathrm{III})$ ) at acidic condition promotes the efficiency of $\mathrm{Cr}(\mathrm{VI})$ removal, which was also suggested by other reports in the literature $[3,4]$.

Since the maximum $\mathrm{Cr}(\mathrm{VI})$ adsorption (91.95\%) was obtained at $\mathrm{pH} \mathrm{3}$, this $\mathrm{pH}$ was selected as the optimum. This result is in good agreement with the previous studies $[24,25]$. In a further related studies, pH 3 was also reported as the optimal $\mathrm{pH}$ for the removal of $\mathrm{Cr}(\mathrm{VI})$ once nZVI- $\mathrm{Fe}_{3} \mathrm{O}_{4}$ nanocomposites, active carbon and saw dust adsorbents were employed [2,25,26].

\section{Effect of contact time}

Figure 4(b) illustrates the effect of contact time on the $\mathrm{Cr}(\mathrm{VI})$ adsorption at the following condition: $0.3 \mathrm{~g} / \mathrm{l}$ solution of the adsorbent, optimal $\mathrm{pH}(\mathrm{pH}=3.0 \pm 0.1)$ and the contact time of $120 \mathrm{~min}$. As indicated in Figure 4(b), the $\mathrm{Cr}(\mathrm{VI})$ adsorption efficiency was increased sharply up to $60 \mathrm{~min}$ and then it reached the equilibrium state right after $60 \mathrm{~min}$. The sharp increase in the adsorption efficiency may be due to the existence of enormous vacant active sites in the adsorbent surface. However, by raising the contact time the availability of $\mathrm{Cr}(\mathrm{VI})$ ions to the active sites on the adsorbent surface is limited, which makes the adsorption efficiency reduce [21]. In a similar study, this phenomenon was investigated using different adsorbents [27,28]. In a further related study, Tang et al. reported that the adsorption of $\mathrm{Cr}(\mathrm{VI})$ on nano-carbonate hydroxyl apatite reached the equilibrium state at $90 \mathrm{~min}$ at different concentrations of $\mathrm{Cr}(\mathrm{VI})$ [29]. Since $90 \mathrm{~min}$ is more than the optimal time obtained in the present study, it can be noted that the
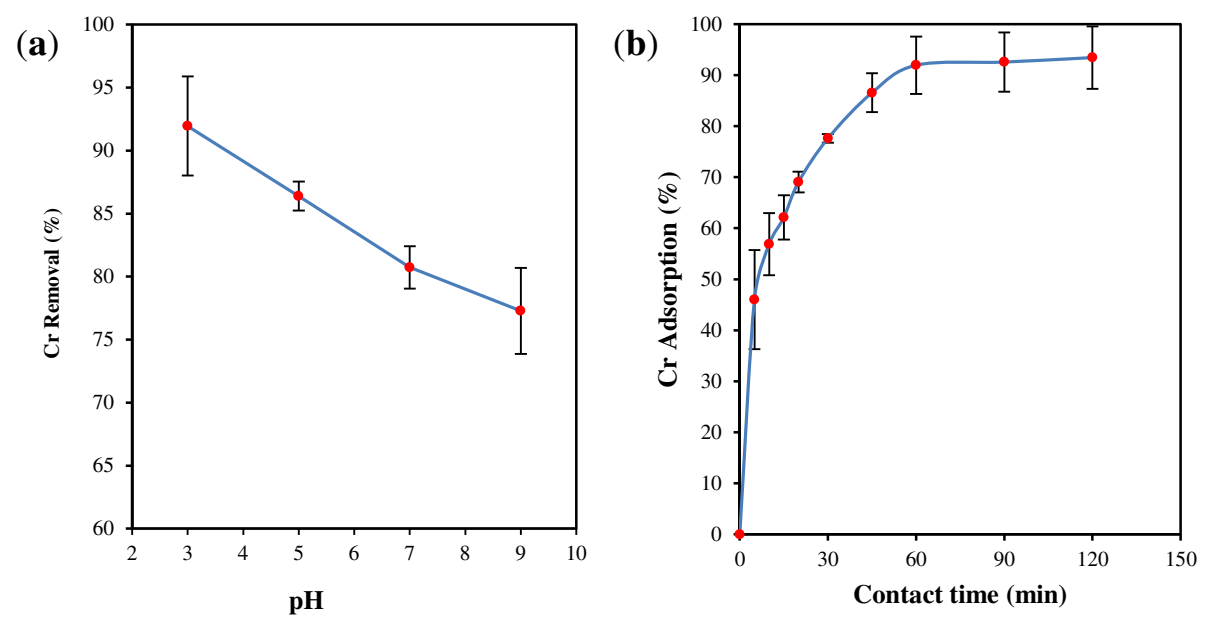

Figure 4 Effect of $\mathrm{pH}$ (a) and contact time (b) on adsorption $\mathrm{Cr}(\mathrm{VI})$ onto PAC-Fe $/ \mathrm{Ag}$ (200 rpm agitation speed, $0.3 \mathrm{~g} / \mathrm{l}$ adsorbent, $4 \mathrm{mg} / \mathrm{L}$ initial $\mathrm{Cr}(\mathrm{VI})$ concentration and $\left.20 \pm 1^{\circ} \mathrm{C}\right)$. 


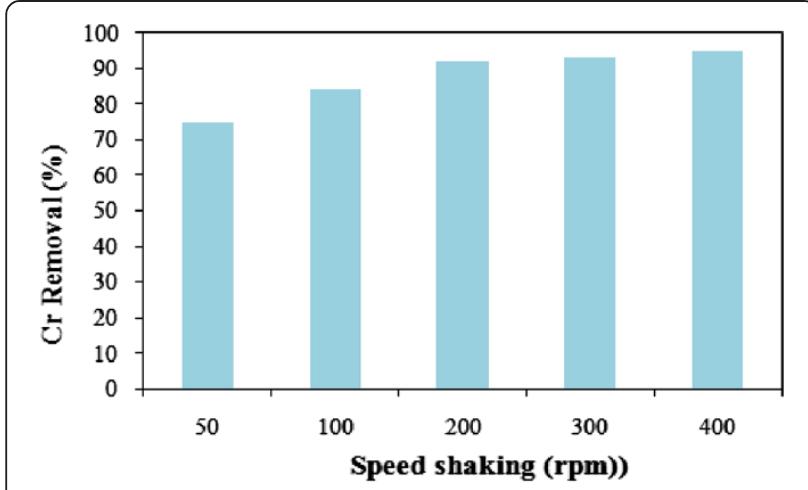

Figure 5 Effect of agitation speed on $\mathrm{Cr}(\mathrm{VI})$ removal using $\mathrm{PAC}-\mathrm{Fe} / \mathrm{Ag}\left(\mathrm{C}_{0}=4 \mathrm{mg} / \mathrm{L}, \mathrm{pH}=3.0 \pm 0.1\right.$, contact time $=60 \mathrm{~min}$, adsorbent dose $=0.3 \mathrm{~g} / \mathrm{L}$ and $20 \pm 1{ }^{\circ} \mathrm{C}$ ).

$\mathrm{PAC}-\mathrm{Fe}^{\mathrm{o}} / \mathrm{Ag}$ has higher adsorption rate than nanocarbonate hydroxyl apatite.

\section{Effect of agitation speed}

In batch adsorption systems, agitation speed plays a significant role affecting the external boundary film and the distribution of the solute in the bulk solution [30]. The effect of agitation speed on $\mathrm{Cr}(\mathrm{VI})$ removal efficiency was examined in the range of 50-400 rpm (Figure 5). The results revealed that the $\mathrm{Cr}(\mathrm{VI})$ removal efficiency didn't change beyond the agitation speed of $200 \mathrm{rpm}$. In a related study, Weng et al., reported that this phenomenon can be attributed to the little resistance of the boundary layer and high mobility of the system [30]. Hence, in the next experiments, the agitation speed of $200 \mathrm{rpm}$ was selected as the optimal mixing speed.

\section{Effect of adsorbent dosage}

The effect of different amounts of $\mathrm{PAC}-\mathrm{Fe}^{\mathrm{O}} / \mathrm{Ag}$ on the adsorption capacity and efficiency under the optimal condition ( $\mathrm{pH}=3, \mathrm{t}=60 \mathrm{~min}$ and $200 \mathrm{rpm}$ ) is illustrated in Figure 6(a). It can be observed that with an increase in the adsorbent dosage from 0.1 to $2 \mathrm{~g} / \mathrm{l}$ the removal efficiency increased from 71.60 to $97.25 \%$ for $4 \mathrm{mg} / \mathrm{L}$ of $\mathrm{Cr}(\mathrm{VI})$, while the adsorption capacity decreased from 28.64 to $1.95 \mathrm{mg} / \mathrm{g}$. The rise in the adsorption efficiency is related to the increase in the availability of active sites on the $\mathrm{PAC}-\mathrm{Fe}^{\mathrm{O}} / \mathrm{Ag}$, which can give rise to the adsorption of $\mathrm{Cr}(\mathrm{VI})$ ions [12].

Jung et al. [5] reported that with an increase in the dosage of various adsorbents, the $\mathrm{Cr}(\mathrm{VI})$ removal was enhanced [5]. However, a decrease in the adsorption capacity with an increase in the adsorbent dosage is probably due to instauration of the active sites on the adsorbent surface during the adsorption process. This phenomenon can also be due to the aggregation resulting from high adsorbate concentrations, leading to the decrease in the active surface area of the adsorbent [21].

\section{Effect of $\mathrm{Cr}$ different concentrations}

Figure 6(b) shows the effect of different concentrations of $\mathrm{Cr}(\mathrm{VI})(4,10,25,50$ and $100 \mathrm{mg} / \mathrm{L})$ on the efficiency of adsorption process. By increasing the initial $\mathrm{Cr}(\mathrm{VI})$ concentration from 4 to $100 \mathrm{mg} / \mathrm{L}$, the percentage of adsorption decreased from 95.17 to $44.85 \%$. The limit of active sites on the surface of adsorbent seems to be the main reason for the above-mentioned result [2,5]. Figure 6(b) also indicates that increasing the initial concentration of $\mathrm{Cr}(\mathrm{VI})$ has a positive impact on the adsorption capacity. This phenomenon may be attributed to
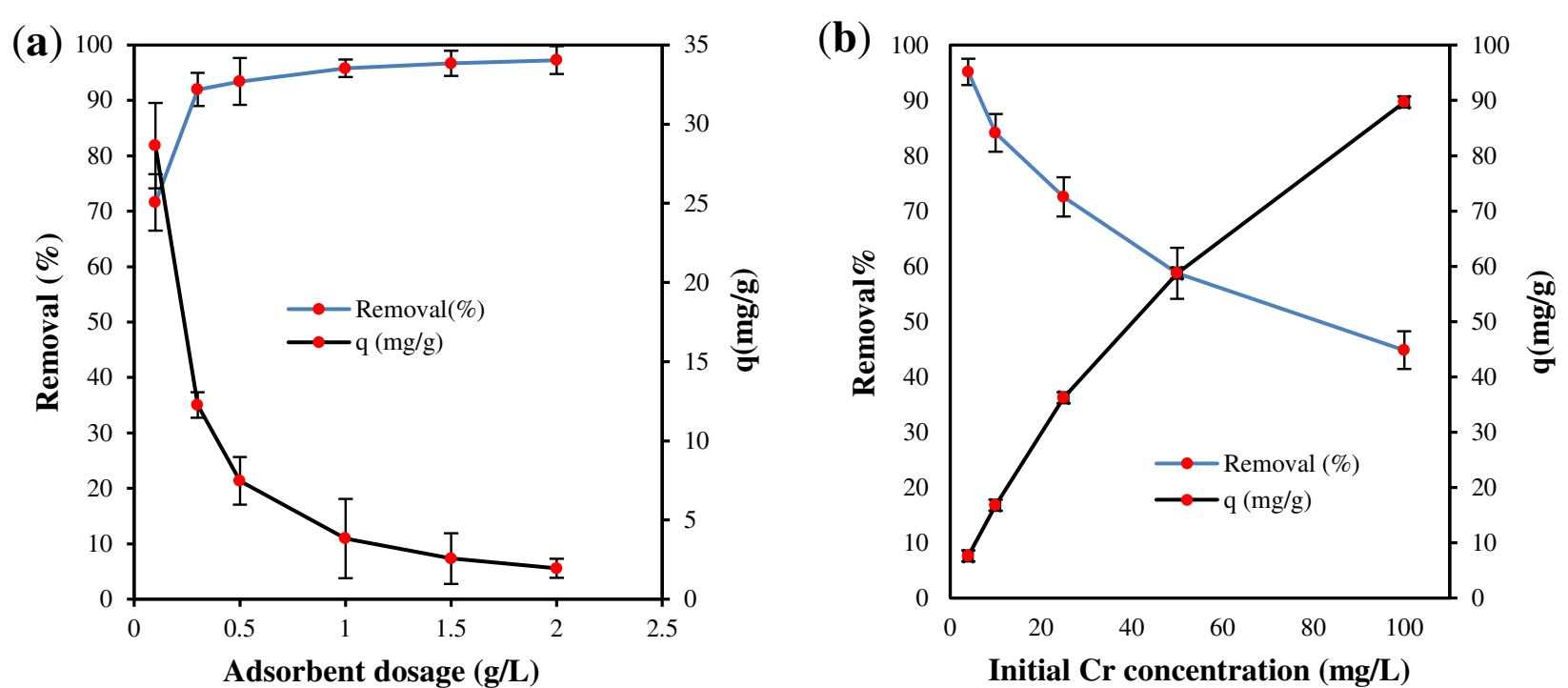

Figure 6 Effect of adsorbent dosage (a) and initial $\mathrm{Cr}(\mathrm{VI})$ concentration (b) on removal efficiency and adsorption capacity of $\mathrm{Cr}$ using $\mathrm{PAC}-\mathrm{Fe} / \mathrm{Ag}\left(\mathrm{pH}=3.0 \pm 0.1\right.$, contact time $=60 \mathrm{~min}$ and $\left.20 \pm 1^{\circ} \mathrm{C}\right)$. 
Table 2 The parameters regarding the adsorption isotherm models for $\mathrm{Cr}(\mathrm{VI})$ adsorption on $\mathrm{PAC}-\mathrm{Fe}^{\circ} / \mathrm{Ag}$

\begin{tabular}{lll}
\hline Isotherm models & Parameters & \\
\hline Freundlich & $\mathrm{q}_{\mathrm{m}}(\mathrm{mg} / \mathrm{g})$ & 100 \\
& $\mathrm{k}_{\mathrm{L}}(\mathrm{L} / \mathrm{mg})$ & 0.15 \\
& $\mathrm{R}^{2}$ & 0.952 \\
& $\mathrm{R}_{\mathrm{L}}$ & 0.625 \\
Langmuir & $\mathrm{k}_{\mathrm{f}}(\mathrm{mg} / \mathrm{g}(\mathrm{Lmg}) / \mathrm{n})$ & 13.83 \\
& $\mathrm{n}$ & 2.1 \\
& $\mathrm{R}^{2}$ & 0.991 \\
\hline
\end{tabular}

the rise in the concentration gradient, which is similar to the findings by Cho and Luo $[1,22]$.

\section{Adsorption isotherm}

The obtained values regarding the Langmuir and Freundlich isotherms for $\mathrm{Cr}(\mathrm{VI})$ adsorption on PAC$\mathrm{Fe}^{\mathrm{O}} / \mathrm{Ag}$ at $25 \pm 1^{\circ} \mathrm{C}$ are shown in Table 2 . It is clear that the correlation coefficient $\left(R^{2}\right)$ for the Freundlich isotherm model $\left(R^{2}>0.99\right)$ is greater than that of the Langmuir isotherm model. This result reveals that the Freundlich model is in good agreement with the experimental data. The plots shown in Figure $7(\mathrm{a}, \mathrm{b})$ also imply that the Freundlich model can be fitted to the experimental data. In fact, this model suggests that the active sites on the adsorbent surface are distributed in homogeneous form, and the adsorption of $\mathrm{Cr}(\mathrm{VI})$ on $\mathrm{PAC}-\mathrm{Fe}^{\mathrm{O}} / \mathrm{Ag}$ takes palace in a multilayer adsorption manner [31]. From Table 2, it is also observed that the values of $\mathrm{R}_{\mathrm{L}}$ lie between 0 and 1 , indicating that the $\mathrm{Cr}(\mathrm{VI})$ ions have been desirably adsorbed on $\mathrm{PAC}-\mathrm{Fe}^{\mathrm{O}} / \mathrm{Ag}$ [12]. Similar results have been reported by other researchers in the study of $\mathrm{Cr}(\mathrm{VI})$ adsorption on multiwall carbon nanotubes and the activated carbon produced from waste rubber tires [5,32].

Table 3 presents a comparison between the adsorption capacities of various adsorbents for the removal of $\mathrm{Cr}$ (VI). The maximum uptake of $\mathrm{Cr}(\mathrm{VI})$ per mass unit of PAC- $\mathrm{Fe}^{\mathrm{O}} / \mathrm{Ag}$ was found to be $100 \mathrm{mg} / \mathrm{g}$ based on the Langmuir model. Also from Table 3, it is deducted that the activated carbon modified by nZVI and silver bimetallic nanoparticles has a good adsorption capacity compared to the other adsorbents.

\section{Kinetics of adsorption}

The kinetic models' constant values of the adsorption process of $\mathrm{Cr}(\mathrm{VI})$ on $\mathrm{PAC}-\mathrm{Fe}^{\mathrm{o}} / \mathrm{Ag}$ along with their corresponding regression coefficients are given in Table 4. Based on the regression coefficient $\left(R^{2}\right)$, the adsorption kinetics of $\mathrm{Cr}(\mathrm{VI})$ can be better described by the pseudo
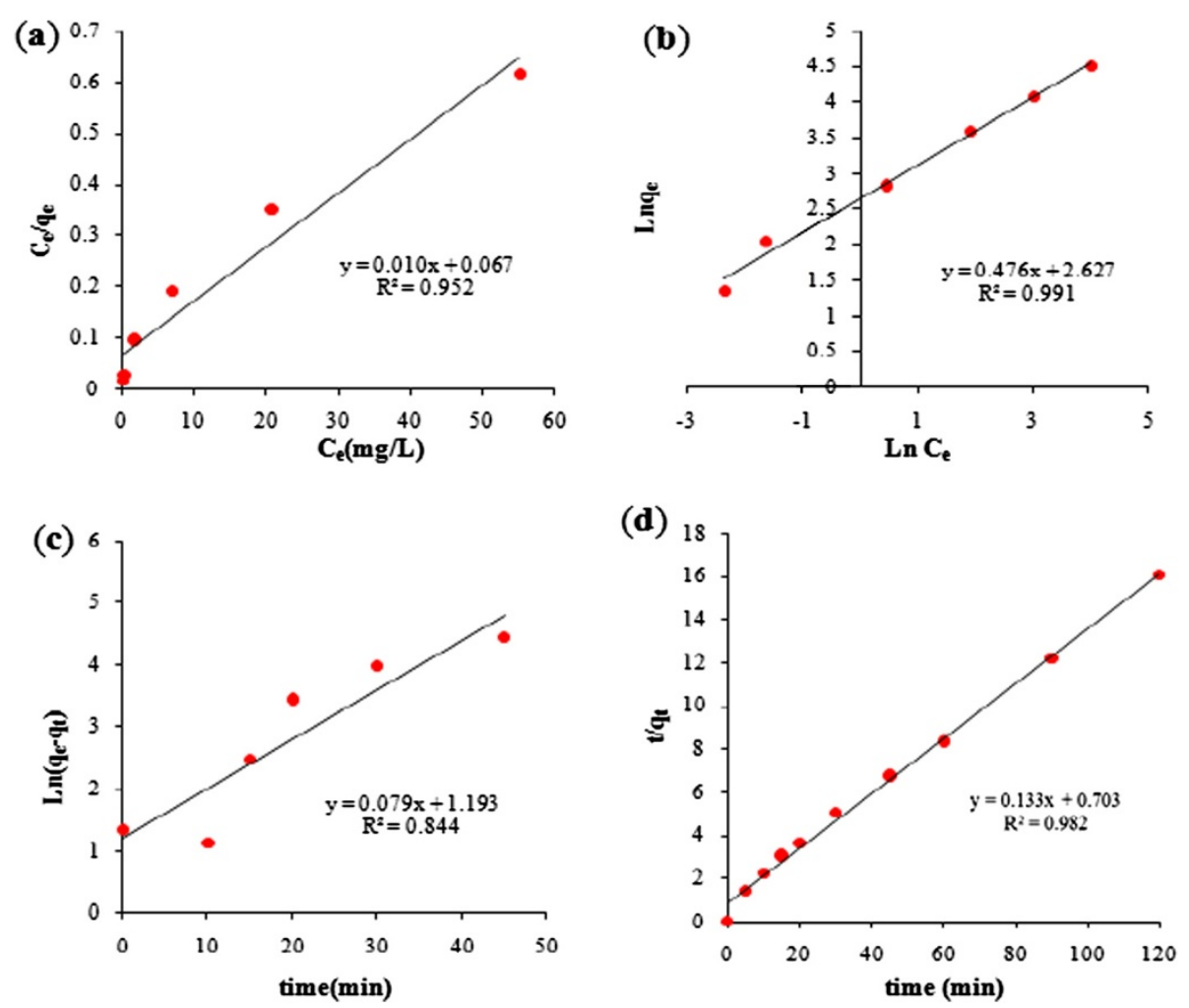

Figure 7 The Langmuir (a), Freundlich (b) isotherm models and pseudo first-order (c) and pseudo second-order (d) kinetic models for the adsorption of $\mathrm{Cr}(\mathrm{VI})$ on $\mathrm{PAC}-\mathrm{Fe} / \mathrm{Ag}$. 
Table 3 Maximum adsorption capacities $\left(q_{m}\right)$ of $\mathrm{Cr}(\mathrm{VI})$ on $\mathrm{PAC}-\mathrm{Fe}^{\circ} / \mathrm{Ag}$ and the other adsorbents documented in the literature

\begin{tabular}{|c|c|c|}
\hline Adsorbent & $q_{m}(m g / g)$ & References \\
\hline $\mathrm{PAC}-\mathrm{Fe}^{\circ} / \mathrm{Ag}$ & 100.0 & This study \\
\hline Graphene oxide & 65.2 & [33] \\
\hline Single-wall carbon nanotubes & 20.3 & {$[5]$} \\
\hline $\mathrm{nZVI}-\mathrm{Fe}_{3} \mathrm{O}_{4}$ nanocomposites & 100.0 & {$[2]$} \\
\hline Activated carbon & 3.46 & {$[26]$} \\
\hline Saw dust & 20.70 & {$[25]$} \\
\hline Chitosan & 35.6 & {$[5]$} \\
\hline MWCNTs $\left(\mathrm{HNO}_{3}\right)$ & 9.5 & [34] \\
\hline $\mathrm{MnO}_{2} / \mathrm{Fe}_{3} \mathrm{O}_{4} / \mathrm{o}-\mathrm{MWCNTS}$ & 186.9 & [1] \\
\hline Powdered activated carbon & 46.9 & {$[5]$} \\
\hline Maghemite nanoparticles & 19.2 & {$[35]$} \\
\hline Multi-wall carbon nanotubes & 2.48 & {$[5]$} \\
\hline
\end{tabular}

second-order model. This result is also confirmed by the curves presented in Figure 7(c, d).

The analysis of data from the pseudo second-order equation suggests that the adsorption of $\mathrm{Cr}(\mathrm{VI})$ onto $\mathrm{PAC}-\mathrm{Fe}^{\mathrm{O}} / \mathrm{Ag}$ is controlled by chemisorptions $[21,36]$. In addition, Table 4 also indicates that the adsorption capacity $\left(\mathrm{q}_{\mathrm{e}, \mathrm{cal}}\right)$ calculated from the pseudo second-order model is well suited to the experimental data $\left(\mathrm{q}_{\mathrm{e}, \exp }\right)$. Therefore, it can be concluded that the kinetics of $\mathrm{Cr}$ (VI) adsorption on PAC- $\mathrm{Fe}^{\mathrm{o}} / \mathrm{Ag}$ fits best to the pseudo second-order model, which is in agreement with the previous reports on $\mathrm{Cr}(\mathrm{VI})$ adsorption [1,5,37]. This result also confirms that adsorption rather than reduction is more likely to be the predominant mechanism (i.e., the rate-limiting step of the process) [2].

\section{Thermodynamics of adsorption}

The thermodynamic curves of $\mathrm{Cr}(\mathrm{VI})$ adsorption and the respective parameters are illustrated in Figure 8 and Table 5, respectively. It is noted in Table 5 that the amount of $\Delta \mathrm{H}^{\mathrm{o}}$ was found to be $146.99 \mathrm{KJ} / \mathrm{mol}$. The positive value of $\Delta \mathrm{H}^{\mathrm{o}}$ indicates that $\mathrm{Cr}(\mathrm{VI})$ adsorption on $\mathrm{PAC}-\mathrm{Fe}^{\mathrm{O}} / \mathrm{Ag}$ is of an endothermic nature [18]. On the other hand, the negative value of $\Delta G^{\circ}$ indicates that

Table 4 The parameters regarding the adsorption kinetic models of $\mathrm{Cr}(\mathrm{VI})$ on $\mathrm{PAC}-\mathrm{Fe}^{\circ} / \mathrm{Ag}$

\begin{tabular}{llll}
\hline Kinetic models & Parameters & & $\mathbf{q}_{\mathbf{e}, \text { exp }}$ \\
\hline Pseudo first-order & $\mathrm{q}_{\mathrm{e}, \text { cal }}(\mathrm{mg} / \mathrm{g})$ & 3.3 & 7.22 \\
& $\mathrm{k}_{1}\left(\mathrm{~min}^{-1}\right)$ & 0.79 & \\
& $\mathrm{R}^{2}$ & 0.844 & \\
Pseudo second-order & $\mathrm{q}_{\mathrm{e}, \mathrm{cal}}(\mathrm{mg} / \mathrm{g})$ & 7.51 & \\
& $\mathrm{k}_{2}(\mathrm{~g} / \mathrm{mg})\left(\mathrm{min}^{-1}\right)$ & 0.025 & \\
& $\mathrm{R}^{2}$ & 0.982 & \\
\hline
\end{tabular}

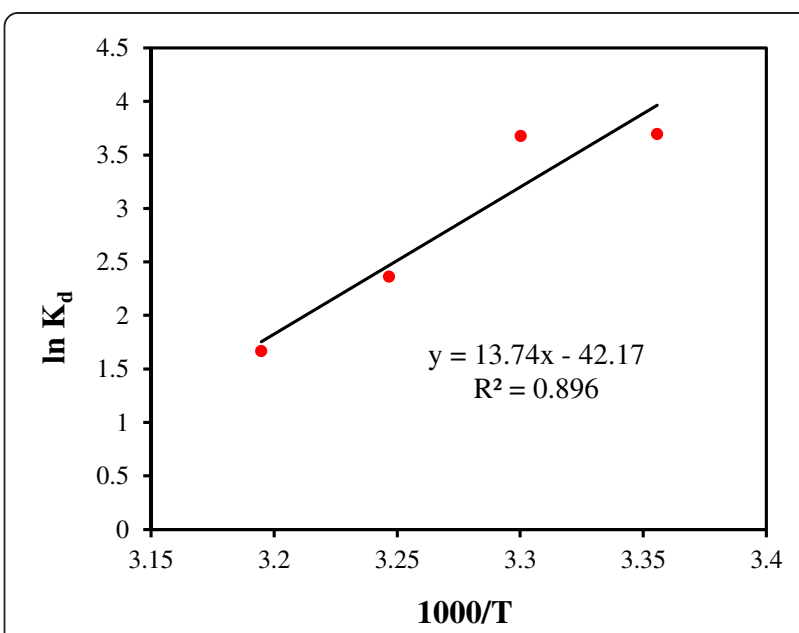

Figure 8 Van't Hoff curve for $\mathrm{Cr}(\mathrm{VI})$ adsorption on PAC-Fe $/ \mathrm{Ag}$.

the $\mathrm{Cr}(\mathrm{VI})$ adsorption process is spontaneous $[1,2]$. According to Table 5 , there is an inverse relationship between the temperature and the amount of $\Delta \mathrm{G}^{\circ}$, which reveals that the adsorbent shows better performance at higher temperatures [18,21]. The amount of $\Delta \mathrm{S}^{\mathrm{o}}$ was also found to be negative $(-0.451 \mathrm{KJ} / \mathrm{mol})$, indicating that with increasing the temperature the adsorption efficiency decreases in solid/liquid phases [12].

\section{Conclusions}

In the present study, the synthesized bimetallic nano composite ( $\mathrm{PAC}-\mathrm{Fe}^{\mathrm{O}} / \mathrm{Ag}$ ) was used as an adsorbent for the removal of $\mathrm{Cr}(\mathrm{VI})$ from the aqueous solutions. The results illustrated that the synthesized adsorbent showed a high efficiency in adsorption of $\mathrm{Cr}(\mathrm{VI})$. The optimum conditions for the adsorption process obtained at acidic $\mathrm{pH}(\mathrm{pH}=3)$, the contact time of $60 \mathrm{~min}$ and the temperature of $50^{\circ} \mathrm{C}$. Moreover, the equilibrium and kinetic studies indicated that the $\mathrm{Cr}(\mathrm{VI})$ adsorption followed the Freundlich isotherm and pseudo secondorder kinetic models. The values regarding the thermodynamic parameters also implied that the adsorption of $\mathrm{Cr}(\mathrm{VI})$ was spontaneous and endothermic in nature. Due to favorable performance of $\mathrm{PAC}-\mathrm{Fe}^{\mathrm{O}} / \mathrm{Ag}$ in the removal of $\mathrm{Cr}(\mathrm{VI})$ and its feasible separation from the aqueous solutions, it can be used as an efficient adsorbent in the treatment of water and wastewater with no

Table 5 The values of thermodynamic parameters of $\mathrm{Cr}$ (VI) adsorption on PAC-Fe $/ \mathrm{Ag}$

\begin{tabular}{lllll}
\hline Temperature $\left({ }^{\circ} \mathbf{K}\right)$ & $\mathbf{I n k}_{\mathbf{d}}$ & $\Delta \mathbf{G}^{\mathbf{O}}(\mathbf{k J} / \mathbf{m o l})$ & $\Delta \mathbf{H}^{\mathbf{}}(\mathbf{k J} / \mathbf{m o l})$ & $\Delta \mathbf{S}^{\mathbf{0}}(\mathbf{k J} / \mathbf{m o l} . \mathbf{K})$ \\
\hline 298 & 3.69 & -9.25 & 146.9 & -0.45 \\
303 & 3.67 & -9.14 & & \\
313 & 2.36 & -6.04 & & \\
323 & 1.66 & -4.33 & & \\
\hline
\end{tabular}


need of further filtering and centrifugation, etc., and also it could be used as an alternative to activated carbon.

\section{Competing interests}

The authors declare that they have no competing interests.

\section{Authors' contribution}

BK carried out all the experiments of the work and also manuscript preparation. AA gives Idea of research and suggested the problem. The research was conducted under the supervision of RRK, MF and AHM. RRK and $A E$ read and revised the manuscript. $A E, A R Y$ and $A B J$ have precipitated in all stages of the study (conducting the experiments, technical analysis of data and manuscript preparation). All authors read and approved the final manuscript.

\section{Acknowledgements}

This study was done by financial support of Tehran University of Medical Sciences and Iranian Nano Technology Initiative Council.

\section{Author details}

'Department of Environmental Health Engineering, School of Public Health, Ahvaz, Jundishapur University of Medical Sciences, Ahvaz, Iran. ${ }^{2}$ Department of Environmental Health Engineering, School of Public Health, Iran University of Medical Sciences, Tehran, Iran. ${ }^{3}$ Department of Environmental Health Engineering, School of Public Health, Tehran University of Medical Sciences, Tehran, Iran. ${ }^{4}$ Center for Solid Waste Research, Institute for Environmental Research, Tehran University of Medical Sciences, Tehran, Iran. ${ }^{5}$ Department of Environmental Health Engineering, School of Public Health, Qom University of Medical Sciences, Qom, Iran. ${ }^{6}$ Department of Environmental Health Engineering, School of Public Health, Shahrood University of Medical Sciences, Semnan, Iran

Received: 28 January 2014 Accepted: 11 August 2014 Published: 21 August 2014

\section{References}

1. Luo C, Tian Z, Yang B, Zhang L, Yan S: Manganese dioxide/iron oxide/acid oxidized multi-walled carbon nanotube magnetic nanocomposite for enhanced hexavalent chromium removal. Chem Eng J 2013, 234:256-265.

2. $L v X, X u J$ J, Jiang $G$, Tang J, Xu X: Highly active nanoscale zero-valent iron (nZVI)-Fe $<$ sub $>3</$ sub $>0<$ sub $>4</$ sub $>$ nanocomposites for the removal of chromium (VI) from aqueous solutions. J Colloid Interface Sci 2012, 369:460-469.

3. Lv X, Xu J, Jiang G, Xu X: Removal of chromium (VI) from wastewater by nanoscale zero-valent iron particles supported on multiwalled carbon nanotubes. Chemosphere 2011, 85:1204-1209.

4. Wu L, Liao L, Lv G, Qin F, He Y, Wang X: Micro-electrolysis of $\mathrm{Cr}(\mathrm{VI})$ in the nanoscale zero-valent iron loaded activated carbon. J Hazard Mater 2013, 254:277-283.

5. Jung C, Heo J, Han J, Her N, Lee S-J, Oh J, Ryu J, Yoon Y: Hexavalent chromium removal by various adsorbents: powdered activated carbon, chitosan, and single/multi-walled carbon nanotubes. Sep Purif Technol 2013, 106:63-71.

6. Vaiopoulou E, Gikas P: Effects of chromium on activated sludge and on the performance of wastewater treatment plants: a review. Water Res 2012, 46:549-570.

7. Ahn CK, Park D, Woo SH, Park JM: Removal of cationic heavy metal from aqueous solution by activated carbon impregnated with anionic surfactants. J Hazard Mater 2009, 164:1130-1136.

8. Vivek Narayanan N, Ganesan M: Use of adsorption using granular activated carbon (GAC) for the enhancement of removal of chromium from synthetic wastewater by electrocoagulation. J Hazard Mater 2009, 161:575-580.

9. Albadarin AB, Mangwandi C, Al-Muhtaseb AH, Walker GM, Allen SJ, Ahmad $M N$ Kinetic and thermodynamics of chromium ions adsorption onto low-cost dolomite adsorbent. Chem Eng J 2012, 179:193-202.

10. Aliabadi M, Khazaei I, Fakhraee H, Mousavian M: Hexavalent chromium removal from aqueous solutions by using low-cost biological wastes: equilibrium and kinetic studies. Int J Environ Sci Technol 2012, 9:319-326.

11. Rocher V, Siaugue J-M, Cabuil V, Bee A: Removal of organic dyes by magnetic alginate beads. Water Res 2008, 42:1290-1298.
12. Kakavandi B, Jonidi Jafari A, Rezaei Kalantary R, Nasseri S, Ameri A, Esrafily A: Synthesis and properties of Fe3O4-activated carbon magnetic nanoparticles for removal of aniline from aqueous solution: equilibrium, kinetic and thermodynamic studies. Iran J Environ Health Sci Engineer 2013, 10:1-9.

13. Luo S, Yang S, Sun C, Gu J-D: Improved debromination of polybrominated diphenyl ethers by bimetallic iron-silver nanoparticles coupled with microwave energy. Sci Total Environ 2012, 429:300-308.

14. $W-x$ Z: Nanoscale iron particles for environmental remediation: an overview. J Nano Res 2003, 5:323-332.

15. Tuan $T Q$, Son NV, Dung HTK, Luong NH, Thuy BT, Anh NTV, Hoa ND, Hai NH: Preparation and properties of silver nanoparticles loaded in activated carbon for biological and environmental applications. J Hazard Mater 2011, 192:1321-1329.

16. Flores C, Diaz C, Rubert A, Benitez G, Moreno M, Fernández Lorenzo de Mele M, Salvarezza R, Schilardi P, Vericat C: Spontaneous adsorption of silver nanoparticles on $\mathrm{Ti} / \mathrm{TiO}<\mathrm{sub}>2</$ sub $>$ surfaces. Antibacterial effect on $<\mathrm{i}>$ Pseudomonas aeruginosa</i $>$. J Colloid Interface Sci 2010, 350:402-408.

17. Ghaedi M, Sadeghian B, Pebdani AA, Sahraei R, Daneshfar A, Duran C: Kinetics, thermodynamics and equilibrium evaluation of direct yellow 12 removal by adsorption onto silver nanoparticles loaded activated carbon. Chem Eng J 2012, 187:133-141.

18. Venkata Ramana D, Yu JS, Seshaiah K: Silver nanoparticles deposited multiwalled carbon nanotubes for removal of Cu (II) and Cd (II) from water: Surface, kinetic, equilibrium, and thermal adsorption properties. Chem Eng J 2013, 223:806-815.

19. Wu X, Yang Q, Xu D, Zhong Y, Luo K, Li X, Chen H, Zeng G: Simultaneous adsorption/reduction of bromate by nanoscale zerovalent iron supported on modified activated carbon. Ind Eng Chem Res 2013, 52:12574-12581.

20. Luo S, Yang S, Wang X, Sun C: Reductive degradation of tetrabromobisphenol A over iron-silver bimetallic nanoparticles under ultrasound radiation. Chemosphere 2010, 79:672-678.

21. Kakavandi B, Esrafili A, Mohseni-Bandpi A, Jafari AJ, Kalantary RR: Magnetic Fe 304 (C nanoparticles as adsorbents for removal of amoxicillin from aqueous solution. Water Sci Technol 2014, 69:147-155.

22. Cho H-H, Wepasnick K, Smith BA, Bangash FK, Fairbrother DH, Ball WP: Sorption of aqueous $\mathrm{Zn}$ [II] and $\mathrm{Cd}$ [II] by multiwall carbon nanotubes: the relative roles of oxygen-containing functional groups and graphenic carbon. Langmuir 2009, 26:967-981.

23. Yuan P, Liu D, Fan M, Yang D, Zhu R, Ge F, Zhu J, He H: Removal of hexavalent chromium [Cr (VI)] from aqueous solutions by the diatomite-supported/unsupported magnetite nanoparticles. $J$ Hazard Mater 2010, 173:614-621.

24. Suksabye P, Thiravetyan P, Nakbanpote W, Chayabutra S: Chromium removal from electroplating wastewater by coir pith. $J$ Hazard Mater 2007, 141:637-644

25. Bhattacharya A, Naiya T, Mandal S, Das S: Adsorption, kinetics and equilibrium studies on removal of $\mathrm{Cr}(\mathrm{VI})$ from aqueous solutions using different low-cost adsorbents. Chem Eng J 2008, 137:529-541.

26. Selvi K, Pattabhi S, Kadirvelu K: Removal of $\mathrm{Cr}(\mathrm{VI})$ from aqueous solution by adsorption onto activated carbon. Bioreso Technol 2001, 80:87-89.

27. Devi BV, Jahagirdar A, Ahmed MZ: Adsorption of chromium on activated carbon prepared from coconut shell. Adsorption 2012, 2:364-370.

28. Li W, Tang Y, Zeng Y, Tong Z, Liang D, Cui W: Adsorption behavior of $\mathrm{Cr}$ (VI) ions on tannin-immobilized activated clay. Chem Eng J 2012 193:88-95.

29. Tang W-Q, Zeng R-Y, Feng Y-L, Li X-M, Zhen W: Removal of Cr (VI) from aqueous solution by nano-carbonate hydroxylapatite of different $\mathrm{Ca} / \mathrm{P}$ molar ratios. Chem Eng J 2013, 223:340-346.

30. Weng C-H, Lin Y-T, Tzeng T-W: Removal of methylene blue from aqueous solution by adsorption onto pineapple leaf powder. J Hazard Mater 2009, 170:417-424.

31. ALzaydien AS: Adsorption of methylene blue from aqueous solution onto a low-cost natural Jordanian Tripoli. American J Environ Sci 2009, 5:197.

32. Gupta VK, Ali I, Saleh TA, Siddiqui M, Agarwal S: Chromium removal from water by activated carbon developed from waste rubber tires. Environ Sci Pollut Res 2013, 20:1261-1268.

33. Fan L, Luo C, Sun M, Qiu H: Synthesis of graphene oxide decorated with magnetic cyclodextrin for fast chromium removal. J Mater Chem 2012, 22:24577-24583. 
34. Tuzen M, Soylak M: Multiwalled carbon nanotubes for speciation of chromium in environmental samples. J Hazard Mater 2007, 147:219-225.

35. Hu J, Lo I, Chen G: Performance and mechanism of chromate (VI) adsorption by $\delta$-FeOOH-coated maghemite $(\gamma-\mathrm{Fe}<\mathrm{sub}>2</$ sub $>0<$ sub $>3</$ sub $>$ ) nanoparticles. Sep Purif Technol 2007, 58:76-82.

36. Momčilović M, Purenović M, Bojić A, Zarubica A, Ranđelović M: Removal of lead (II) ions from aqueous solutions by adsorption onto pine cone activated carbon. Desalination 2011, 276:53-59.

37. Selvarani M, Prema P: Removal of toxic metal hexavalent chromium [cr (vi)] from aqueous solution using starch-stabilized nanoscale zerovalent iron as adsorbent: equilibrium and kinetics. Int J Environ Sci 2012, 2:1962-1975.

doi:10.1186/s40201-014-0115-5

Cite this article as: Kakavandi et al:: Enhanced chromium (VI) removal using activated carbon modified by zero valent iron and silver bimetallic nanoparticles. Journal of Environmental Health Science \& Engineering 2014 12:115.

\section{Submit your next manuscript to BioMed Central and take full advantage of:}

- Convenient online submission

- Thorough peer review

- No space constraints or color figure charges

- Immediate publication on acceptance

- Inclusion in PubMed, CAS, Scopus and Google Scholar

- Research which is freely available for redistribution 